\title{
Isolation and Identification of Ten Genera of Plant Parasitic Nematodes
}

\author{
M. M. Rahman and I. H. Mian* \\ Department of Plant Pathology, Bangabandhu Sheikh Mujibur Rahman Agricultural University, \\ Gazipur 1706, Bangladesh
}

\begin{abstract}
A study was undertaken to isolate and identify different genera of plant parasitic nematodes from soil and plant samples during July to October 2007 in the Laboratory of Plant Pathology at Bangabandhu Sheikh Mujibur Rahman Agricultural University (BSMRAU), Gazipur, Bangladesh. Altogether 10 (Ten) nematodes belonging to 10 genera were isolated and identified from various soil and plant samples. For identification of plant parasitic nematodes, stylet and other anatomical structures such as Dorsal esophageal Gland Orifice (DGO), Esophageal lumen, Median bulb, Basal bulb, Intestine, Reproductive structures (vagina and its position, specula ) Tail types etc. were used as main criteria. Among 10 (ten) different identified genera of nematodes (Criconemoids sp., Hemicriconemoides sp., Tylenchus sp., Ditylenchus sp., Tylenchorhynchus sp., Hoplolaimus sp., Helicotylenchus sp., Pratylenchus sp., Meloidogyne sp., Radinaphelenchus sp.) maximum nematodes were under the family of Tylenchidae. The abundance numbers of plant parasitic nematodes were found as the Ditylenchus sp.(Ufra nematode) and Meloidogyne sp.(Root knot nematode) which were the serious plant pathogens causing ufra in rice and root knot in different crops respectively, so far recorded in Bangladesh.
\end{abstract}

Key words: Isolation, Identification, Plant parasitic nematodes.

\section{Introduction}

Nematodes are important pests of crop plants in both developed and developing countries of the world. They cause appreciable crop damage in tropical, subtropical and temperate zones. The annual worldwide losses caused by nematodes on the life sustaining crops, which include all grains and legumes, banana, cassava, coconut, potato, sugar beet, sugarcane and sweet potato are estimated to be about $11 \%$ and loss for most other economically important crops (vegetables, fruits and non edible field crops) are about $14 \%$ for a total of over $\$ 80$ billion annually (Agrios, G. N. 1997). A diverse mixture of plant parasitic nematodes and free living nematodes (non parasitic) are present in most soil samples. These nematodes can be easily isolated from both soil and root samples for viewing and identification and the identification of the actual pathogen is essential for disease control more effectively (Trigiano et al. 2004).

More than 15 thousand species of nematodes have been described throughout the world. Of these 2200 species are identified as plant parasitic (Goodey et al., 1965). But very little is known about the phytoparasitic nematodes of Bangladesh (Timm and Ameen, 1960; Talukdar, 1974; Choudhury et al.1981). Considering the above facts the pres- ent study was done for isolation and the identification of plant parasitic nematodes.

\section{Materials and Methods}

Plant parasitic nematodes are generally isolated from the roots of plants they infect or from the soil surrounding the roots on which they feed. Suspected soil samples, roots and foliar plant parts were collected from crop fields of Bangabandhu Sheikh Mujibur Rahman Agricultural University (BSMRAU), Gazipur, Bangladesh, Bangladesh Agricultural Research Institute (BARI) and Bangladesh Rice Research Institute (BRRI), Gazipur. A convenient method of collecting soil samples were $15-20 \mathrm{~cm}$ deep and the samples were with a portion of the root system and some of the distance foliage. The whole soil sample was about $1 \mathrm{~L}$ in volume. After collection the soil samples were carrying and stored in a polythene bag. Collected samples were placed following Bearmann Funnel Technique. The active nematodes moved through the tissue, leaving debris behind and concentrated at the bottom of the rubber tube. After 24 hours we collected suspected nematodes containing water funnel into Syracuse dish and observed it under dissecting micro-

\footnotetext{
*Corresponding author: E-mail:
} 
scope and plant parasitic nematodes were observed under compound microscope, noted different structures possessing stylet, and finally identified with the help of pictorial key to genera of plant parasitic nematodes (Mai and Lyon 1975).

\section{Results and Discussion}

Under compound microscope different structures such as types of stylet, esophagus, median bulb, basal bulb, reproductive organ and tails etc. were observed, noted and identified the different genera of plant parasitic nematodes with help of key to genera of plant parasitic nematodes. A total number of 10 different genera of nematodes were identified which were belong to the order Tylenchida and they were under four different families such as Tylenchidae, Criconematidae, Heteroderidae and Aphelenchoididae were presented in Table I. Among them most were under the family Tylenchidae.

\section{Identification of different nematodes}

Identifying characters: During identification, the following characters were observed

\section{Class: Secernentea}

Esophagus with 3 or 4 distinct region, Order: TylenchidaNematode with axial stylet, bursa present or absent, 1) Super family: Tylenchoidea- Lumen not straight into median bulb, outlet of DGO near base of stylet, median bulb roundish, fusiform or absent.

\section{(a) Family: Criconematidae}

Nematodes are heavily annulated, stylets well developed in females and very long, esophagus with amalgamated procorpus and median bulb (Criconematoid type), basal esophageal gland abutting and without overlapping lobe; (i) Sub-family:

Table I. Identified ten genera of plant parasitic nematodes with their systematic position and identifying characters

\begin{tabular}{|c|c|c|c|}
\hline Sl No. & Genera of nematode & Systematic position & Identifying characters of genera \\
\hline 1 & $\begin{array}{l}\text { Criconemoids sp. } \\
\text { (Ring nematode) }\end{array}$ & $\begin{array}{l}\text { Class : Secernentea } \\
\text { Order : Tylenchida } \\
\text { Super family: Tylenchoidea } \\
\text { Family : Criconematidae } \\
\text { Sub-family: Criconemainae }\end{array}$ & $\begin{array}{l}\text { Not retaining fourth moult sheath, annules } \\
\text { smoth or crenate, spine absent, tail blunt }\end{array}$ \\
\hline 2 & Hemicriconemoides sp. & $\begin{array}{l}\text { Class : Secernentea } \\
\text { Order : Tylenchida } \\
\text { Super family: Tylenchoidea } \\
\text { Family : Criconematidae } \\
\text { Sub-family: Criconemainae }\end{array}$ & $\begin{array}{l}\text { Annulations are very smooth than } \\
\text { Criconemoids sp., spine absent, tails conoid }\end{array}$ \\
\hline 3 & Tylenchorhynchus sp. & $\begin{array}{l}\text { Class : Secernentea } \\
\text { Order : Tylenchida } \\
\text { Super family: Tylenchoidea } \\
\text { Family : Tylenchidae } \\
\text { Sub-family: Tylenchinae }\end{array}$ & $\begin{array}{l}\text { Esophagus abutting, tail-blunt or rounded, } 2 \\
\text { ovaries, distance from anterior end of esoph- } \\
\text { agus to median bulb less than distance from } \\
\text { median bulb to intestine. }\end{array}$ \\
\hline 4 & Tylenchus sp. & $\begin{array}{l}\text { Class : Secernentea } \\
\text { Order : Tylenchida } \\
\text { Super family: Tylenchoidea } \\
\text { Family : Tylenchidae } \\
\text { Sub-family: Tylenchinae }\end{array}$ & $\begin{array}{l}\text { Ovary one, female not saccate, male with } \\
\text { bursa, body of female slender, adult found in } \\
\text { soil, distance from anterior end of esophagus } \\
\text { to median bulb less than distance from medi- } \\
\text { an bulb to intestine }\end{array}$ \\
\hline 5 & Ditylenchus angustus & $\begin{array}{l}\text { Class : Secernentea } \\
\text { Order : Tylenchida } \\
\text { Super family: Tylenchoidea } \\
\text { Family : Tylenchidae } \\
\text { Sub-family: Tylenchinae }\end{array}$ & $\begin{array}{l}\text { Tail conoid, bursa long, lip region not striat- } \\
\text { ed, and larger bodies than Tylenchus. }\end{array}$ \\
\hline
\end{tabular}


Table I continued

\begin{tabular}{|c|c|c|c|}
\hline Sl No. & Genera of nematode & Systematic position & Identifying characters of genera \\
\hline 6 & Hoplolaimus sp. & $\begin{array}{l}\text { Class : Secernentea } \\
\text { Order : Tylenchida } \\
\text { Super family: Tylenchoidea } \\
\text { Family : Tylenchidae } \\
\text { Sub-family: Hoplolaiminae }\end{array}$ & $\begin{array}{l}\text { Spear knob anchor shaped with distinct ante- } \\
\text { rior projection, tail hemispherical, shorter } \\
\text { than anal body diameter. }\end{array}$ \\
\hline 7 & Helicotylenchus sp & $\begin{array}{l}\text { Class : Secernentea } \\
\text { Order : Tylenchida } \\
\text { Super family: Tylenchoidea } \\
\text { Family : Tylenchidae } \\
\text { Sub-family: Hoplolaiminae }\end{array}$ & $\begin{array}{l}\text { Basal bulb overlap ventrally on intestine } \\
\text { (spiral nematode), tail conoid. }\end{array}$ \\
\hline 8 & $\begin{array}{l}\text { Pratylenchus sp. } \\
\text { (Lesion nematode) }\end{array}$ & $\begin{array}{l}\text { Class : Secernentea } \\
\text { Order : Tylenchida } \\
\text { Super family: Tylenchoidea } \\
\text { Family : Tylenchidae } \\
\text { Sub-family: Hoplolaiminae }\end{array}$ & $\begin{array}{l}\text { Ovary single, prodelphic, vulva posterior } \\
\text { (between } 70 \text { and } 90 \text { percent). }\end{array}$ \\
\hline 9 & $\begin{array}{l}\text { Meloidogyne sp. } \\
\text { (Root knot nematode) }\end{array}$ & $\begin{array}{l}\text { Class : Secernentea } \\
\text { Order : Tylenchida } \\
\text { Super family: Tylenchoidea } \\
\text { Family : Heteroderidae }\end{array}$ & $\begin{array}{l}\text { Excretory pore at level with stylet or close } \\
\text { behind it, usually marked galling of the host } \\
\text { roots, fat body observed (juvenile). }\end{array}$ \\
\hline 10 & $\begin{array}{l}\text { Radinaphelenchus sp. } \\
\text { (Red ring nematode) }\end{array}$ & $\begin{array}{l}\text { Class : Secernentea } \\
\text { Order : Tylenchida } \\
\text { Super-family: Aphelenchoidea } \\
\text { Family: Aphelenchoididae }\end{array}$ & $\begin{array}{l}\text { Very narrow and long nematodes ( } \mathrm{a}=\text { around } \\
\text { 100), vulva with wide overlapping flap, vagi- } \\
\text { na curved. }\end{array}$ \\
\hline
\end{tabular}

Criconematinae- Female with one ovary, annulations extremely pronounced, retrorse or with double cuticle, isthmus and terminal bulb of esophagus form a short rounded cylinder;

\section{(b) Family: Tylenchidae}

Esophagus abutting, tail-blunt or rounded, 2 ovaries, distance from anterior end of esophagus to median bulb less than distance from median bulb to intestine;

\section{(c) Family: Heteroderidae}

Excretory pore at level with stylet or close behind it, usually marked galling of the host roots, fat body observed (juve nile). 2) Super family: Aphelenchoidea- Lumen straight into median into bulb, outlet of DGO in median bulb, median bulb a prominent feature, usually somewhat oblong
(Squarish); (a) Family: Aphelenchoididae- Lumen straight into median into bulb, outlet of DGO in median bulb, median bulb a prominent feature, usually somewhat oblong (Squarish).

\section{Conclusion}

From the findings of the study it may be concluded that active and alive nematodes can be isolated by Bearmann Funnel Technique. Plant parasitic nematodes must be posses axial stylet while non parasitic is lack of axial stylet. For identification of plant pathogenic nematodes stylet and other anatomical structures such as dorsal esophageal Gland Orifice (DGO), Esophageal lumen, Median bulb, Basal bulb, Intestine, Reproductive structures (vagina and its position, spicule), Tail types etc. were very useful. Among 10 (ten) identified genera of nematodes maximum nematodes were 
under the family of Tylenchidae. This study will be more helpful to the student and plant pathologists for nematode identification.

\section{References}

Agrios G. N. (1997). Plant Pathology, 4th ed. Academic Press, New York.

Choudhury B. C., Isabel MC Geachie and M.O. Hoque, (1981). A preliminary investigation on parasitic nematodes associated with banana in Joydevpur. Bangladesh Hort. 9: 41-44.

Goodey J. B., M. T. Franklin and D.J.Hooper (1965). The nematode parasites of plants catalogued under their hosts, CAB. Farham Royal, Bucks, England 213pp.
Mai W. F. and H. H. Lyon (1975). Pictorial Key to Genera of Plant Parasitic Nematodes. Cornel University Press, Ithaca, NY, 219 pp.

Talukdar M. J. (1974). Plant diseases in Bangladesh. Bangladesh J. Agric. Res. 1: 61-86.

Timm R. W. and M.Ameen (1960). Nematodes associated with commercial crops of East Pakistan. Agric. Pak. 11: 355-363.

Trigiano R. N., Windhum M. T. and Windham A. S. (2004). Plant Patholoy: Concept and Laboratory Exercise. CRC Press, New York.

Received : January 14, 2009;

Accepted : August 04, 2010 